\title{
Pattern and outcome of perforated peptic ulcer disease patient in four teaching hospitals in Addis Ababa, Ethiopia: a prospective cohort multicenter study
}

Jatani Arero Bupicha, Hailu Wondimu Gebresellassie* (10) and Abebe Alemayehu

\begin{abstract}
Background: Perforated peptic ulcer disease is a surgical emergency with a high morbidity and mortality. The socio-demographic characteristic and the factors associated with morbidity and mortality seems to differ between the developed and developing world. This is the first a prospective cohort study in Ethiopia designed to analyze pattern and outcome of patients with perforated peptic ulcer disease in four teaching hospitals affiliated with SOM, CHS of Addis Ababa University.

Method: This is a prospective cohort study of patients operated for perforated peptic ulcer disease from June 1 , 2018 to May 31, 2019 in four teaching hospital affiliated to department of surgery of SOM, CHS of Addis Ababa university.

Result: A total of 97 patients were operated in a year. $86.6 \%$ were males with a male to female ratio of $6.5: 1$. The age group 21-30 were most affected constituting $42.3 \%$ of all patients. Mean age is 31.9 , Median of 27, age ranges from 16 to 76 . Alcohol use (45.4\%) and previous history of ulcer disease (75.3\%) were the most prevalent risk factors.33\% were smokers. Abdominal was present in all and most presented within $48 \mathrm{~h} \mathrm{(79.4 \% ).85.6 \%} \mathrm{had}$ pneumo = peritoneum in an x-ray at presentation. Size of the perforation is $10 \mathrm{~mm}$ or less in $81.3 \% .91(93.8 \%)$ had anterior first part duodenum perforation. Repair with pedicled omental patch was done in 65 (67.1\%) patients. Age, duration of presentation, hypotension at presentation, size of perforation, degree of peritoneal contamination were found to be the significant factors for morbidity and mortality. Major morbidities were observed in 16 (16.5\%) and mortality occurred in 3 (3.1\%) patients.

Conclusion: Perforation of peptic ulcer disease here occurs in the young. Age, duration of presentation, hypotension at presentation, size of perforation, degree of peritoneal contamination were found to be the significant factors for morbidity and mortality. Morbidity and mortality rate of 16.5 and 3.1\% observed here are quite acceptable.
\end{abstract}

Keywords: Perforation, Peptic ulcer disease, Morbidity, Mortality, Pattern

\footnotetext{
*Correspondence: hailuwgs@gmail.com; hailu.wondimu@aau.edu.et
} CHS, SOM, AAU, Addis Ababa, Ethiopia

(c) The Author(s). 2020 Open Access This article is licensed under a Creative Commons Attribution 4.0 International License, which permits use, sharing, adaptation, distribution and reproduction in any medium or format, as long as you give appropriate credit to the original author(s) and the source, provide a link to the Creative Commons licence, and indicate if changes were made. The images or other third party material in this article are included in the article's Creative Commons licence, unless indicated otherwise in a credit line to the material. If material is not included in the article's Creative Commons licence and your intended use is not permitted by statutory regulation or exceeds the permitted use, you will need to obtain permission directly from the copyright holder. To view a copy of this licence, visit http://creativecommons.org/licenses/by/4.0/. The Creative Commons Public Domain Dedication waiver (http://creativecommons.org/publicdomain/zero/1.0/) applies to the data made available in this article, unless otherwise stated in a credit line to the data. 


\section{Background}

The natural history of peptic ulcer disease ranges from spontaneous resolution without intervention to development of life threatening complication such as bleeding and perforations. Perforated peptic ulcer is the 2nd most common ulcer related emergency following bleeding [1].

Perforated peptic ulcer is a surgical emergency and is associated with short-term mortality in up to $30 \%$ of patients and morbidity in up to 50\% [1]. Worldwide variations in demography, socioeconomic status, Helicobacter pylori prevalence, and prescription drugs make investigation into risk factors for perforated peptic ulcer difficult [2].

Peptic ulcer related morbidity and mortality decreased in the western world since the mid-twentieth century especially in the young but ulcer mortality in senior citizens has, none the less, remained essentially unchanged or even increased [3].

The situation is different in the developing part of the world like Ethiopia where perforated PUD remains to be one of the top causes of acute abdomen and emergency surgery. Recent publication from Ethiopia put perforated peptic ulcer disease to be 3rd most common cause of acute abdomen following appendicitis and intestinal obstruction. More over our patients are younger, males are affected much more than females and the vast majority of perforations are duodenal $[4,5]$.

Most of the risk factors associated with perforation such as alcohol, smoking are well known but some may be related to local habits such as use of khat (Catha edulis), a stimulant leaf widely used in east Africa and Arabian peninsula and known for many gastrointestinal adverse effects [6].

Various techniques of closure (and their modifications) of the perforation were described such as simple closure, closure with vascularized omental pedicle (Cellon-Jones) and free omental plug (Graham's). Putting a sub-hepatic drain after closure is being practiced in some centers like ours although its value is not substantiated [7].

The situation of the patient at presentation, delay at presentation and surgical intervention are now well known to be related to outcome of the patient [8].

\section{Methods}

\section{Ethics approval and consent to participate}

Ethical approval were gained from research and publication committee of department and approved by school of medicine in May 2018 reference number Dept. of surgery/SOM/61. Patients were counselled and written agreement obtained.

\section{Patient selection}

All consecutive patients operated for perforated peptic ulcer disease in the four teaching hospitals (Minilik hospital, Yekatit-12 hospital, Zewditu Memorial Hospital, Tikur Anbessa specialized hospital) affiliated to department of surgery of school of medicine from June 1, 2018 to May 31, 2019 are included in the study.

\section{Patient management}

All patients were initially resuscitated with crystalloids, nasogastric tube inserted, urinary bladder catheterized and metronidazole and 3rd generation cephalosporin often ceftriaxone started. Informed consent for emergency surgery obtained. Laparotomy done and the intra-abdominal situation assessed. The intra-peritoneal sucked out and a thorough lavage with warm saline done. Then the perforation were dealt with either free omental patch or a vascularized pedicled omental patch depending on the preference of operating surgeon.

\section{Statistical analysis}

Patient demography, possible risk factors, status at presentation, intra-operative findings, post-operative complications and final outcome were collected and filled in to a pre-prepared format. Patients were followed from admission to discharge or death. The data were collected by surgical residents and interns and checked by the authors.

Statistical analysis was performed using IBM-SPSSversion-25 statistical package. The mean standard deviation (SD), median and ranges were calculated for continuous variables whereas proportions and frequency tables were used to summarize categorical variables. Chi-square test was used to test for the significance of association between the independent (predictor) and dependent (outcome) variables in the categorical variables. The level of significance was considered as $\mathrm{P}<0.05$.

\section{Results}

\section{Patients' background}

During the study period 97 patients were operated. 84 (86.6\%) were males and $13(13.4 \%)$ were females with a male to female ratio of 6.5 to 1. Patients' age ranged from 16 to 76, Mean age of 31.9, Median of 27. Only 15 (15.5\%) came outside the city. $77.3 \%$ were orthodox Christians and $16.5 \%$ were Muslims. Regular alcohol use were reported by $44(45.4 \%)$ and smoking in the third (33\%) of all patients. Use of the local addictive stimulant khat (Catha edulis) were found in 17 (17.5\%) of patients. Although $73(75.3 \%)$ patients gave history of PUD the Helicobacter Pylori status of 90 (92.8\%) were known at the time of presentation. Perforation occurred while fasting $13(13.4 \%)$ patients (Table 1).

Forty four (45.4\%) presented within $24 \mathrm{~h}, 33$ patients presented between 24 and $48 \mathrm{~h}$ after onset of abdominal pain. Abdominal pain were the presenting complaint in all patients and physical examination revealed generalized 
Table 1 Socio-demographic data of patients with perforated Peptic ulcer disease in four teaching hospital in Addis Ababa, Ethiopia

\begin{tabular}{|c|c|c|c|}
\hline Category & & Number & Percentage \\
\hline \multirow[t]{3}{*}{ GENDER } & Male & 84 & 86.6 \\
\hline & Female & 13 & 13.4 \\
\hline & \multicolumn{3}{|l|}{ Male: Female ratio 6.5: 1} \\
\hline \multirow[t]{8}{*}{ Age } & \multicolumn{3}{|c|}{ Mean age of 31.9,Median of 27,Age range from 16 to 76} \\
\hline & $11-20$ & 17 & 17.5 \\
\hline & $21-30$ & 41 & 42.3 \\
\hline & $31-40$ & 23 & 23.7 \\
\hline & $41-50$ & 4 & 4.1 \\
\hline & $51-60$ & 6 & 6.2 \\
\hline & $61-70$ & 4 & 4.1 \\
\hline & $71-80$ & 2 & 2.1 \\
\hline \multirow[t]{2}{*}{ Address } & Addis Ababa & 82 & 84.5 \\
\hline & Outside Addis Ababa & 15 & 15.5 \\
\hline \multirow[t]{3}{*}{ Religion } & Orthodox Christian & 75 & 77.3 \\
\hline & Muslims & 16 & 16.5 \\
\hline & Other Christians & 6 & 6.2 \\
\hline \multirow[t]{2}{*}{ Alcohol use } & Yes & 44 & 45.4 \\
\hline & No & 53 & 54.6 \\
\hline \multirow[t]{2}{*}{ Khat use (Catha edulis) } & Yes & 17 & 17.5 \\
\hline & No & 80 & 82.5 \\
\hline \multirow[t]{2}{*}{ Smoking } & yes & 32 & 33 \\
\hline & No & 65 & 67 \\
\hline \multirow[t]{2}{*}{ Co-morbidity } & present & 3 & 3.1 \\
\hline & Absent & 94 & 96.9 \\
\hline \multirow[t]{2}{*}{ NSAID use } & Present & 2 & 2.1 \\
\hline & absent & 95 & 97.9 \\
\hline Fasting & present & 13 & 13.4 \\
\hline \multirow[t]{4}{*}{ season } & summer & 18 & 18.6 \\
\hline & autumn & 19 & 19.6 \\
\hline & winter & 26 & 26.7 \\
\hline & spring & 34 & 35.1 \\
\hline \multirow{5}{*}{$\begin{array}{l}\text { History of PUD } \\
\text { H. pylori infection }\end{array}$} & Present & 73 & 75.3 \\
\hline & absent & 24 & 24.7 \\
\hline & positive & 3 & 3.1 \\
\hline & Negative & 4 & 4.1 \\
\hline & unknown & 90 & 92.8 \\
\hline
\end{tabular}

peritonitis in $85(87.6 \%)$ patients. 17 (17.5\%) had hypotension and raised WBC count were observed in 45 (46.4\%). X-ray evidence of free peritoneal air were found in 83 of the $97(85.6 \%)$ patients (Table 2).

\section{Intraoperative finding and procedure done}

The location of the perforation were in the first part of duodenum anteriorly in 91 (93.8\%) and the size of the perforation was less than $10 \mathrm{~mm}$ in diameter in 79
(81.3\%). Less than a liter of peritoneal GI content were found in $72(74.2 \%)$ patients.

Repair with vascularized omental patch were performed in $65(67.1 \%)$ and free omental patch in 28 (28.8\%) patients (Table 2 and Table 3 ).

\section{Postoperative outcome}

Major complications such as surgical site infection, pneumonia, post-operative collection and patch failure 
Table 2 Clinical and operative findings of patients with perforated Peptic ulcer disease in four teaching hospital in Addis Ababa, Ethiopia

\begin{tabular}{|c|c|c|c|}
\hline Clinical presentation & & number & $\%$ \\
\hline \multirow[t]{3}{*}{ Presenting complaint } & Abdominal pain & 97 & 100 \\
\hline & vomiting & 82 & 84.5 \\
\hline & Abdominal distension & 78 & 80.4 \\
\hline \multirow[t]{4}{*}{ Duration of presentation } & $<24 h$ & 44 & 45.4 \\
\hline & $24-48 h$ & 33 & 34 \\
\hline & $48-72 h$ & 10 & 10.3 \\
\hline & $>72 \mathrm{~h}$ & 10 & 10.3 \\
\hline \multirow[t]{2}{*}{ Physical finding } & Generalized peritonitis & 85 & 87.6 \\
\hline & Localized peritonitis & 12 & 12.4 \\
\hline \multirow[t]{2}{*}{ Hypotension at presentation } & present & 17 & 17.5 \\
\hline & absent & 80 & 82.5 \\
\hline \multirow[t]{2}{*}{ WBC count at presentation } & leukocytosis & 45 & 46.4 \\
\hline & normal & 52 & 53.6 \\
\hline \multirow[t]{3}{*}{ Chest $\mathrm{x}$ ray finding } & positive & 83 & 85.6 \\
\hline & negative & 11 & 11.3 \\
\hline & Not done & 3 & 3.1 \\
\hline \multirow[t]{3}{*}{ Size of perforation } & $<10 \mathrm{~mm}$ in diameter & 79 & 81.3 \\
\hline & 10-20 in diameter & 12 & 12.4 \\
\hline & $>20$ mm diameter & 2 & 2.1 \\
\hline \multirow[t]{3}{*}{ Location of perforation } & duodenal & 91 & 93.8 \\
\hline & Pre-pyloric/gastric & 2 & 2.1 \\
\hline & Sealed ant duodenal & 4 & 4.1 \\
\hline \multirow[t]{3}{*}{ Degree of peritoneal contamination } & $<11$ & 72 & 74.2 \\
\hline & $1-2 \mid$ & 21 & 21.6 \\
\hline & $>31$ & 4 & 4.1 \\
\hline
\end{tabular}

were observed in 16 (16.5\%) of the patients. 94 (96.6\%) were discharged improved and 3 (3.1\%) died. The majority (53 patients or 54.6\%) were discharged within 7 days (Table 4).

Analysis in terms of morbidity and mortality of the possible risk factors showed higher age ( $>40$ years), longer duration at presentation $(>48 \mathrm{~h})$, hypotension at presentation, higher degree of peritoneal contamination were significant risk factors $(\mathrm{P}<0.05)($ Table 5$)$.

Table 3 Method of repair perforated Peptic ulcer disease in four teaching hospital in Addis Ababa, Ethiopia

\begin{tabular}{lll}
\hline Repair method & Number & $\%$ \\
\hline Simple repair & 0 & 0 \\
Repair with omental reinforcement & 65 & 67.1 \\
Graham's omental patch & 28 & 28.8 \\
Sealed no patch needed & 4 & 4.1 \\
Sub-hepatic drain inserted & 89 & 91.8 \\
\hline
\end{tabular}

\section{Discussion}

This study showed that male to female ratio of patients with perforated peptic ulcer disease is 6.5 to 1.0. This is similar the two studies done in hospitals here in Addis Ababa by Assefa $\mathrm{Z}$ and Ersemo $\mathrm{T}$ where the male to female ratio was reported to be 6.6: 1and 5.6:1.0 respectively. A study by Phillipo L Chalya et al. from Tanzania showed the male to female ratio of only 1.3 to $1[9,10]$. This difference in incidence do not seem to be the case in developed countries as a study by Thorsen $\mathrm{K}$ et al. on epidemiology of perforated peptic ulcer disease in Norway showed that females are affected more than males (that 89 of 172 of their patients were females) [11].

The mean age of patients in this study is just 31.9 and $42.3 \%$ of our patients were aged between 21 and 30 suggesting that our patients here in Ethiopia are much younger than most other reports. Two studies from Nigeria (one on Five-Year Review of Perforated Peptic Ulcer Disease in Irrua, Nigeria by A. E. Dongo et al. and another on Audit of Perforated Peptic Ulcer Disease in a 
Table 4 Morbidity mortality, hospital stay duration patients with perforated Peptic ulcer disease in four teaching hospital in Addis Ababa, Ethiopia

\begin{tabular}{|c|c|c|c|}
\hline Variables & & Number & $\%$ \\
\hline \multirow[t]{3}{*}{ Hospital stay } & $<7$ days & 53 & 54.6 \\
\hline & $7-14$ days & 33 & 34.0 \\
\hline & $>14$ days & 11 & 11.3 \\
\hline \multirow[t]{6}{*}{ Morbidity } & Patch failure & 5 & 5.2 \\
\hline & SSI & 5 & 5.2 \\
\hline & pneumonia & 5 & 5.2 \\
\hline & Post-operative collection & 1 & 1.1 \\
\hline & Re-laparotomy (for patch failure \& recollection) & 5 & 5.1 \\
\hline & Total & 16 & 16.5 \\
\hline \multirow[t]{2}{*}{ outcome } & Discharged improved & 94 & 96.6 \\
\hline & Died & 3 & 3.1 \\
\hline
\end{tabular}

Tropical Teaching Hospital) showed the pick age of their patients to be on 5th decade $[12,13]$ and patients with PUD perforation in developed countries are even more older as seen by the study in Norway by Thorsen $\mathrm{K}$ et al. (68\% of their patients were aged 60 years or older).

Similar to a previous study by Abebe B in Minilik II hospital, most of our patients (84.5\%) came from the capital city Addis Ababa [14].

A regular use of alcohol and smoking were found in 45.4 and $33 \%$ of our patients respectively. A study in a tertiary hospital in Tanzania $85.7 \%$ use alcohol and $64.3 \%$ were smokers. A study from eastern India by Nishith M Paul Ekka and Shital Malua also reported $65.73 \%$ were known smokers while $42.86 \%$ patients were admittedly alcoholics $[15,16]$.

Consumption of the stimulant leaf Khat (Catha edulis) which is wide spread in eastern Africa and Arabian Peninsula were found in nearly one in five of our patients (17.5\%) with PUD perforation. This is much lower than the finding in a study on pattern and seasonal variation of PUD perforation in this city by Abebe B and his colleagues where $50.5 \%$ were found to be a regular consumer. Another study from Zewditu Memorial hospital by Assefa $\mathrm{Z}$ and G/eyesus A. showed $75 \%$ of their patients' with PUD perforation use Khat. The use of this substance is associated with a number of gastrointestinal problems $[9,14]$.

$75.3 \%$ of our patients gave history of PUD and this is similar to reports from Tanzania where 69\% had PUD history but the study in Irrua, Nigeria $59.6 \%$ had no history of peptic ulcer disease [17]

Unlike the studies in developed countries like Norway comorbidities and use of NSAID were found in only in 3.1 and $2.1 \%$ respectively in this study but a study in Ghana by J. C. B. Dakubo and his colleagues revealed a regular ingestion of NSAIDS in $47.7 \%$ patients and 18.2\% had associated co-morbid conditions [18].
Among the seasons of the year perforation occurred more in the spring (March 1 to May 31) which happens to be the fasting months for both Orthodox Christian and Muslims in Ethiopia but only 13.4\% were fasting when the perforation occurred. This has been reported to be the case in some studies [19].

Abdominal pain were the presenting complaint in all of our patients followed by vomiting and abdominal distension similar to finding Nigerian study by A. E. Dongo et al. Nearly half $(45.4 \%)$ our patients came within $24 \mathrm{~h}$ of onset this is similar to the study in in Accra, Ghana but a study on presentation and management of Perforated Peptic Ulcer Disease in a Tertiary Centre In South Nigeria by Dodiyi-Manuel A et al. only $11.1 \%$ patients presented within $24 \mathrm{~h}$ of the onset of symptoms $[17,20]$.

Generalized peritonitis were present on 85 of $97 \mathrm{pa}-$ tients $(87.6 \%)$ in this study and this is similar to the study in eastern India where $97.8 \%$ of their patients had abdominal rigidity or guarding. The study from Tanzania also showed that abdominal tenderness and classical signs of peritonitis were demonstrable in 88.1 and $66.7 \%$ patients respectively [18].

In this study hypotension at presentation were observed in only 17 of $97(17.5 \%)$ patients but the Tanzanian study reported shock occurred in 33.3\% of their patients. Leukocytosis were found in $45 / 97$ our patients $(46.4 \%)$ but $91.2 \%$ had leukocytosis in the Indian study [16].

Air under diaphragm was found in 83 of the $97(85.6 \%)$ patients in this study similar a clinical study of peptic ulcer perforation in eastern India where $82.41 \%$ patients showed radiological sign of gas under diaphragm $[13,16]$.

The location of the perforation is first part of duodenum in $93.8 \%$ of our patients. This is similar to the study in Northwestern Tanzania where most perforations were located on the duodenum $\{92.9 \%)$, whereas in the 
Table 5 Factors influencing morbidity and mortality on bivariate logistic regression of patients with perforated Peptic ulcer disease in four teaching hospital in Addis Ababa, Ethiopia

\begin{tabular}{|c|c|c|c|c|c|c|c|}
\hline Variable & & $\begin{array}{l}\text { Complications } \\
N(\%) \\
N=16\end{array}$ & $\begin{array}{l}\text { No Complications } \\
N(\%) \\
N=68\end{array}$ & $P$-value & $\begin{array}{l}\text { Death } \\
N(\%) \\
N=3\end{array}$ & $\begin{array}{l}\text { Discharged improved } \\
N(\%) \\
N=94\end{array}$ & $P$-value \\
\hline \multirow[t]{2}{*}{ Sex } & Male & $16(19.04)$ & $68(80.1)$ & & $3(3.6)$ & $81(96.4)$ & \\
\hline & Female & $0(0)$ & $13(100)$ & 0.136 & 0 & 13 & 0.787 \\
\hline \multirow[t]{7}{*}{ Age } & $11-20$ & $3(17.6)$ & $14(82.4)$ & & $0(0)$ & $17(100)$ & \\
\hline & $21-30$ & $4(9.8)$ & $37(90.2)$ & & $0(0)$ & $41(100)$ & \\
\hline & $31-40$ & $4(17.4)$ & 19 (82.6) & & $2(8.7)$ & 21(91.3) & \\
\hline & $41-50$ & $1(25)$ & $3(75)$ & & $0(0)$ & $4(100)$ & \\
\hline & $51-60$ & $1(16.7)$ & $5(83.3)$ & & $0(0)$ & $6(100)$ & \\
\hline & $61-70$ & $2(50)$ & $2(50)$ & & $1(25)$ & $3(75)$ & \\
\hline & $71-80$ & $1(50)$ & $1(50)$ & 0.08 & $0(0)$ & $2(100)$ & 0.003 \\
\hline \multirow[t]{2}{*}{ Address } & $\mathrm{AA}$ & $12(14.6)$ & $70(85.4)$ & & $3(3.6)$ & 79(96.4) & \\
\hline & Outside & $4(26.7)$ & $11(73.3)$ & 0.391 & $0(0)$ & $15(100)$ & 0.475 \\
\hline \multirow[t]{3}{*}{ Religion } & Orthodox & 11(14.9) & $63(85.1)$ & & $2(2.7)$ & $73(98.3)$ & \\
\hline & Muslim & $4(25)$ & $12(75)$ & & $1(6.3)$ & $15(93.7)$ & \\
\hline & Others Christians & $0(0)$ & $6(100)$ & 0.310 & $0(0)$ & $6(100)$ & 0.746 \\
\hline \multirow[t]{2}{*}{ History of PUD } & History of PUD & $13(17.8)$ & $60(82.2)$ & & $3(4.1)$ & $70(95.90$ & \\
\hline & No history of PUD & $3(12.50$ & $21(87.50$ & & $0(0)$ & $24(100)$ & 0.337 \\
\hline \multirow[t]{2}{*}{ Smoking } & Yes & $5(15.6)$ & $27(84.40)$ & & $0(0)$ & $32(100)$ & \\
\hline & No & $11(16.9)$ & $54(84.10$ & 0.922 & $3(4.6)$ & $62(95.4)$ & 0.240 \\
\hline \multirow[t]{2}{*}{ Alcohol } & Yes & $4(16.4)$ & $38(83.6)$ & & $0(0)$ & $44(100)$ & \\
\hline & No & $10(18.70)$ & $43(81.3)$ & 0.212 & & & 0.126 \\
\hline \multirow[t]{2}{*}{ Khat use/Catha edulis } & Yes & $2(12.5)$ & $14(87.5)$ & & $1(5.9)$ & $16(94.1)$ & \\
\hline & NO & $15(18.5)$ & $66(81.5)$ & 0.141 & $2(2.5)$ & 78 (97.5) & 0.323 \\
\hline \multirow[t]{2}{*}{ Co-morbidity } & Yes & $0(0)$ & $3(100)$ & & $1(33.3)$ & $2(66.70$ & \\
\hline & & $16(17)$ & 78(83) & & & & 0.00 \\
\hline \multirow[t]{2}{*}{ NSAID use } & yes & $1(50)$ & $1(50)$ & & $0(0)$ & $2(100)$ & \\
\hline & No & $15(15.8)$ & $80(84.2)$ & 0.076 & $3(3.2)$ & 92(96.8) & 0.809 \\
\hline \multirow[t]{2}{*}{ Hx of PUD } & Yes & 13(17.8) & $60(82.2)$ & & $3(4.1)$ & 70 (95.9) & \\
\hline & No & $3(12.5)$ & $21(87.5)$ & 0.139 & 0 & 0 & \\
\hline H.Pylri infection & Present & $1(33.3)$ & $2(66.7)$ & 0.647 & $1(33.3)$ & $2(66.70$ & 0.02 \\
\hline \multirow[t]{4}{*}{ Duration at presentation } & $<24 \mathrm{~h}$ & $4(9)$ & $40(91)$ & & $0(0)$ & $44(100)$ & \\
\hline & $24-48 \mathrm{~h}$. & $5(15.1)$ & $28(84.9)$ & & $1(3)$ & $32(97)$ & \\
\hline & $48-72 \mathrm{~h}$. & $3(27.3)$ & $7(72.7)$ & & $0(0)$ & $10(100)$ & \\
\hline & $>72 \mathrm{~h}$. & $4(40)$ & $6(60)$ & 0.004 & $2(20)$ & $8(80)$ & 0.003 \\
\hline \multirow[t]{2}{*}{ WBC count } & Raised & $7(15.6)$ & $38(84.4)$ & & $0(0)$ & $45(100)$ & \\
\hline & Normal & $9(17.3)$ & $43(82.7)$ & 0.610 & $3(5.8)$ & $49(94.2)$ & \\
\hline \multirow[t]{3}{*}{ CXR finding } & Free air & $14(16.7)$ & $69(83.3)$ & & $2(2.4)$ & 81(97.6) & \\
\hline & Not detected & $1(9.1)$ & $10(90.9)$ & & $0(0)$ & $11(100)$ & \\
\hline & Not done & $1(33.3)$ & $2(66.7)$ & & $1(33.3)$ & $2(66.7)$ & \\
\hline Hypotension & Yes & $9(52.9)$ & $8(47.1)$ & 0.000 & $3(17.6)$ & $14(82.4)$ & 0.001 \\
\hline \multirow[t]{3}{*}{ Perforation size } & $<10 \mathrm{~mm}$ & $7(9.2)$ & 69 (90.8) & & $0(0)$ & 79 (100) & \\
\hline & $10-20 \mathrm{~mm}$ & $5(41.7)$ & $7(59.3)$ & & $1(8.3)$ & 11(91.7) & \\
\hline & $>20 \mathrm{~mm}$ & $1(50)$ & $1(50)$ & & $2(100)$ & $0(0)$ & 0.000 \\
\hline
\end{tabular}


Table 5 Factors influencing morbidity and mortality on bivariate logistic regression of patients with perforated Peptic ulcer disease in four teaching hospital in Addis Ababa, Ethiopia (Continued)

\begin{tabular}{|c|c|c|c|c|c|c|c|}
\hline Variable & & $\begin{array}{l}\text { Complications } \\
N(\%) \\
N=16\end{array}$ & $\begin{array}{l}\text { No Complications } \\
N(\%) \\
N=68\end{array}$ & $P$-value & $\begin{array}{l}\text { Death } \\
N(\%) \\
N=3\end{array}$ & $\begin{array}{l}\text { Discharged improved } \\
N(\%) \\
N=94\end{array}$ & $P$-value \\
\hline & Sealed & $0(0)$ & $4(100)$ & 0,046 & $0(0)$ & $1(100)$ & \\
\hline \multirow[t]{3}{*}{ contamination } & $<1 \mathrm{Lts}$ & $7(9.7)$ & $65(90.3)$ & & $1(1.4)$ & 71 (98.6) & \\
\hline & 1-3 Lts & $7(33.3)$ & $14(66.7)$ & & $1(4.8)$ & $20(95.2)$ & \\
\hline & $>3$ Lts & $1(33.3)$ & $2(66.7)$ & 0.000 & $1(25)$ & $3(75)$ & 0.006 \\
\hline \multirow[t]{3}{*}{ Procedure done } & Simple closure & $0(0)$ & $0(0)$ & & $0(0)$ & $0(0)$ & \\
\hline & Pedicled omental & $11(16.9)$ & $54(83.1)$ & & $3(4.6)$ & 62(95.4) & \\
\hline & Free omental & $5(18.5)$ & $23(81.5)$ & 0.399 & $0(0)$ & $27(100)$ & \\
\hline Drainage left & & $15(16.8)$ & 74 (83.2) & & $3(3.4)$ & 86 (96.6) & \\
\hline
\end{tabular}

remaining $7.1 \%$ patients had their ulcers located on the stomach. Reports from Norway, The Netherlands and Iceland showed gastric ulcer perforation predominate over duodenal perforations in that part world [21].

The size of the perforation is $<10 \mathrm{~mm}$ in diameter in $81.3 \%$ of our patients but this was not the finding in a study on Clinical profile and outcome of surgical treatment of perforated peptic ulcers in Northwestern Tanzania where thirteen $(15.5 \%)$ of the perforations were of minimal size $(\leq 5 \mathrm{~mm})$ and sixty-four $(76.2 \%)$ were massive $(>10 \mathrm{~mm})$. Another study from in Irrua, Nigeria showed $49 \%$ of perforations had a diameter of $<10 \mathrm{~mm}$ [22].

Repair with pedicle omental patch was done in $67.1 \%$, free Grahams omental patch in $28.8 \%$ and 4 (4.1\%) were found to have a sealed perforation in this study. Graham's Omentopexy was procedure of choice in Nigerian study accounting for $69.2 \%$. Ibadan Nigeria Simple closure was performed in $25 \%$, pedicled omental plug done in $60 \%$ and primary closure with an onlay omentum in $15 \%$ of the patients $[18,20]$.

In this study significant morbidities (such as patch failure, pneumonia, SSI) occurred in 16 of 97 patients (16.5\%) and this is acceptable and lower than most reports from Africa. We have three postoperative deaths making mortality rate $3.1 \%$ similar to SeungJin et al. where an overall 30 -day mortality rate to be $3.17 \%$.(The statistically significant factors associated with increased morbidity and mortality in this study with a P-value less than 0.05 were older age, hypotension at presentation, delay at presentation and perforation greater than $10 \mathrm{~mm}$ in diameter. In a paper that summarize the evidence for perforated peptic ulcer management and identify directions for future clinical research in the Lancet all of the above were described to significant factors for postoperative morbidity and mortality in patients with PUD perforation $[8,23]$.

\section{Conclusion}

Perforation of peptic ulcer disease here occurs in the very young. Age, duration of presentation, hypotension at presentation, size of perforation, degree of peritoneal contamination were found to be the significant factors for morbidity and mortality. Morbidity and mortality rate of 16.5 and $3.1 \%$ observed here quite acceptable.

\section{Abbreviations}

SOM: School of medicine; CHS: College of health sciences; AAU: Addis Ababa university; Gl: Gastrointestinal; PUD: Peptic ulcer disease; AA: Addis Ababa

\section{Acknowledgements}

We would like to thank residents, interns, nurses of the four hospitals for helping out in collecting data. We are also grateful to staff and head of surgery department for the support they provided in preparation and undertaking of the research.

\section{Authors' contributions}

All authors have approved the final version of the manuscript. HWG took part in research proposal preparation, collection, analysis and writing of manuscript of data. JAB wrote the proposal, collected data, participate in analysis as well as writing the manuscript. AA took part in data analysis and in writing of the manuscript.

\section{Funding}

It was partially funded by school of medicine, college of health sciences, Addis Ababa University.

The school of medicine, college of health sciences of AAU covered the cost of collecting data and stationers required. Approved the design of the study but did not take part in analysis, interpretation and writing the manuscript.

\section{Availability of data and materials}

The original data collected and compiled SPSS file is available with corresponding author.

\section{Ethics approval and consent to participate}

Ethical approval were obtained from the department of surgery's research and publication committee as well as the school of medicine of CHS of AAU in a letter dated April 12, 2018. Written consent to participate were obtained from each patient.

\section{Consent for publication}

The department of surgery as well as the school encourage publication of research works. All the participants gave a written consent for their personal and clinical details. 


\section{Competing interests}

The authors have no competing interests to disclose.

Received: 3 December 2019 Accepted: 11 June 2020

Published online: 15 June 2020

\section{References}

1. Vakil NB. In: Feldman M, editor. Epidemiology and etiology of peptic ulcer disease; 2018. Available from: Epidemiology and etiology of peptic ulcer disease - UpToDate.

2. Søreide K, Thorsen K, Harrison EM, Bingener J, Møller MH, Ohene-yeboah M, et al. Perforated peptic ulcer. Lancet. 2015;386:1288-98.

3. Kang JY, Elders A, Majee AD, LI JDM, Bardhan KD. Recent trends in hospital admissions and mortality rates for peptic ulcer in Scotland 1982-2002. Aliment Pharmacol Ther Recent trends Hosp admissions Mortal rates peptic ulcer Scotl 1982-2002 J Y KANG*, A ELDERS,AMAJEEDà,J DMAXWELL* \&K DBARDHAN§ *Department. 2006:24(1):65-79.

4. Gebresellassie HW, Tamerat G. Audit of surgical services in a teaching hospital in Addis Ababa, Ethiopia. BMC Res Notes. 20191-5. Available from. https://doi.org/10.1186/s13104-019-4709-y.

5. Tamrat G, Osman M, Deyessa N, Taye M, Lett R, Bekele A. Delay of emergency surgical interventions in Ethiopia : patient and health system factors. East Cent Afr J Surg. 2018;23(2):59-65.

6. Abdelwahab SI, Alsanosy RM, Rahim BE, et al. Khat (Catha edulis Forsk.) Dependence potential and pattern of use in Saudi Arabia. Biomed Res Int. 2015:2015:604526. https://doi.org/10.1155/2015/604526.

7. Odula PO. Omentoplasty in perforated peptic ulcer surgery : is it still the gold standard? Ann Afr Surg. 2017;14(2):57-60.

8. Bae S, Shim K, Kim N, Kang JM, Kim D, Kim K, et al. Incidence and shortterm mortality from perforated peptic ulcer in Korea : a population-based study. J Epidemiol. 2012;22(6):508-16.

9. Assefa Zelalem GA. Perforated peptic ulcer disease in Zewditu hospital. EMJ. 2012;50(2):145-51.

10. Ersumo T, Ali A, Kotiso B. Complicated peptic ulcer disease in Tikur Anbessa Hospital, Addis Ababa. Ethiop Med J. 2004:42(2):87-95.

11. Thorsen K, Søreide JA, Kvaløy JT, Glomsaker T, Søreide K, Thorsen K, et al. Epidemiology of perforated peptic ulcer : age- and gender- adjusted analysis of incidence and mortality. World J Gastroenterol. 2013;19(3):347-54.

12. Dongo AE, Uhunmwagho O, Kesieme EB, Eluehike SU, Alufohai EF. A five-year review of perforated peptic ulcer disease in Irrua, Nigeria. Int Sch Res Not F 18\% M. 2017;2017Available from. https://doi.org/10.1155/2017/8375398.

13. Afuwape $\mathrm{O}$, Irabor DO, Ayandipo O. An audit of perforated peptic ulcer disease in a tropical teaching hospital. East Cent Afr J surg An. 2013; 18(December):40-4.

14. Bekele A, Zemenfes D, Kassa S, Deneke A, Taye M, Wondimu S. Patterns and seasonal variations of perforated peptic ulcer disease : experience from Ethiopia. Ann AFRICAN Surg. 2017;14(2).

15. Chalya PL, Mabula JB, Koy M, Mchembe MD, Jaka HM, Kabangila R, et al. Clinical profile and outcome of surgical treatment of perforated peptic ulcers in northwestern Tanzania : a tertiary hospital experience. World J Emerg Surg [Internet]. 2011;6(31):1-10 Available from: http://www.wjes.org/ content/6/1/31

16. Ekka NMP, Malua S. Clinical study of peptic ulcer perforation in eastern India : an tertiary institution-based study. Int J Med Sci Public Heal. 2016;5(12): 2540-4

17. Pn W, Vc E. Presentation and management of perforated peptic ulcer disease in a tertiary Centre in south South Nigeria presentation et gestion des ulcère gastroduodénal dans un Centre supérieur au Sud du Sud Nigeria. J West African Coll Surg. 2015:5(3).

18. Wegdam HHJ, Hillah AA. Modified open omental plugging of peptic ulcer perforation in a municipal Hospital in Ghana. Postgrad Med J Ghan. 2013; 2(1):20-3.

19. Agbonrofo Pll rowa Ooo AL. Clinics in surgery seasonal variation of gastro duodenal perforation in. Clin Surg. 2018;3:10-3.

20. Ugochukwu Al, Amu OC, Nzegwu MA, Dilibe UC. Acute perforated peptic ulcer : on clinical experience in an urban tertiary hospital in south East Nigeria acute perforated peptic ulcer : on clinical experience in an urban tertiary hospital in south East Nigeria. IJSU. 2013;11(3):223-7Available from: https://doi.org/10.1016/j.jisu.2013.01.015.

21. Thorsen K Søreide JA, Søreide K. What is the best predictor of mortality in perforated peptic ulcer disease? A population-based, multivariable regression analysis including three clinical scoring systems. J Gastrointest Surg. 2014:18:1261-8.

22. Gona. SKKA. Postoperative morbidity and mortality of perforated peptic ulcer: retrospective cohort. Gastroenterol Res Pract. 2016;2016Available from. https://doi.org/10.1155/2016/2640730

23. Rickard J. Surgery for peptic ulcer disease in sub- Saharan Africa : systematic review of. J Gastrointest Surg. 2016;20(4):840-50.

\section{Publisher's Note}

Springer Nature remains neutral with regard to jurisdictional claims in published maps and institutional affiliations.
Ready to submit your research? Choose BMC and benefit from:

- fast, convenient online submission

- thorough peer review by experienced researchers in your field

- rapid publication on acceptance

- support for research data, including large and complex data types

- gold Open Access which fosters wider collaboration and increased citations

- maximum visibility for your research: over $100 \mathrm{M}$ website views per year

At BMC, research is always in progress.

Learn more biomedcentral.com/submissions 